"Individualism in a Planned Society". She sees administration as a social process which, whether in a Government department, an industry or a business, must be integrated with the purposes and welfare of the society of which the more limited activity forms a part. Her view of administration as a continuous and progressing activity is in line with the ideas advanced by Mannheim in "Man and Society in an Age of Reconstruction", and the final two essays provide as complete an answer to those who reject the idea of planning as they do a corrective to the prejudiced or narrow thinking which sometimes characterizes the approach to management problems. Indeed, their contribution to efficient administration is searcely more direct than it is to the creative thinking by which alone we can evolve the collective controls required to preserve and expand our tradition and heritage of freedom.

\section{R. BRIGHTMAN.}

\title{
THE LIFE OF INVERTEBRATES
}

\section{A General Zoology of the Invertebrates}

By G. S. Carter. Pp. xxviii $+510+13$ plates. (London: Sidgwick and Jackson, Ltd., 1940.) $25 s$.

$\mathrm{I}^{\mathrm{N}}$ $\mathrm{N}$ the periodic swing of interest between form and function morphology had a long innings in the schools of Britain, and even now that the animal alive has won its meed of study, the textbooks in general use scarcely reflect the change in outlook that this century has seen. With a telling contribution to the literature of the classroom Dr. Carter has supplied the missing link, and teacher and student will appreciate the labour of collecting and collation which has gathered in a unified survey the results of many scattered investigations.

Two impressions stand out from a reading of his volume: one is of the broad conception of the plan and the thoroughness of its execution, and the other is of the ease and effectiveness of the writing.

The plan is laid around four major topics. The first deals with the properties of protoplasm, the cells and the 'Protista', which are regarded as single cells, for the author rejects the non-cellular conception of the Protozoa since he looks upon a cell as the unit of organization of all animal protoplasm. The second topic, the multicellular body, gives an opportunity for excellent reviews of such subjects as regeneration, dedifferentiation and reconstitution, axial gradients and organizers, and various aspects of the problem of growth. But we miss here any discussion of ecdysis in the Arthropoda or of discontinuous growth in general, or of the recent work upon various types of cuticle.

Comparative physiology is discussed in the longest and most detailed section of the book, marked by a particularly good account of nervous co-ordination. Finally, general problems of invertebrate zoology include life-histories, comparative behaviour, ecology and evolution. Limitation of space has resulted in a somewhat sketchy treatment of the first three, but the last embodies a very interesting speculation upon the evolutionary relationships of invertebrate phyla. The suggestion is that the Metazoa should be divided into two superphyla - the Echinoderm superphylum, including only Echinoderms and Chordates, characterized by pluteus larva, radial cleavage, equipotential development and enterocœl; and the Annelid superphylum including all the remaining Metazoa, except the Colenterates and Sponges, with trochosphere larva, spiral cleavage, mosaic development and schizocœl.

The distinctions, however, do not always hold, as the author points out, and in the matter of cœlome development it might be stated that Hamann, Dawydoff, and recently H. Barraclough Fell have shown that even in some echinoderms the cœlom is schizocœlic.

The grouping of the Lamellibranchs as sessile animals is unusual ; the figures of the prophase of mitosis scarcely represent the modern view; and in the figures showing parasitic modifications in copepods, that of Achtheres is inaccurate, Penella has an incomplete head, and the series might have been completed by the addition of Xenocœloma, described by Caullery, with its gonads and ducts included in the host and only a pair of egg-sacs outside. The only misprint we have noticed is in the legend of Fig. 51.

These are small matters; the great matter is that here is a work, well indexed, with a useful bibliography mainly of monographs and general reviews, which, as a highly successful and up-todate synthesis of the biology of invertebrates, meets a long-felt need and will give a new drive to the study of the living animal. 